\title{
Study of gonadic growth factors: Seminal transforming growth factor- $\beta 1$, epidermal growth factor and insulin-like growth factor-I and their relationship with male infertility
}

\author{
Houda Amor ${ }^{1}$, Mounir Ajina ${ }^{2}$, Ali Saad ${ }^{1}$, Habib Ben Ali $^{1^{*}}$ \\ ${ }^{1}$ Laboratoire de Cytogénétique, Génétique Moléculaire et Biologie de la Reproduction Humaines, CHU Farhat Hached, Sousse, \\ Tunisie; *Corresponding Author: alihabibsaoudite@yahoo.fr \\ ${ }^{2}$ Unité de Médecine de la Reproduction, CHU Farhat Hached, Sousse, Tunisie
}

Received 3 August 2013; revised 12 September 2013; accepted 1 October 2013

Copyright (C) 2014 Houda Amor et al. This is an open access article distributed under the Creative Commons Attribution License, which permits unrestricted use, distribution, and reproduction in any medium, provided the original work is properly cited. In accordance of the Creative Commons Attribution License all Copyrights ¿ 2014 are reserved for SCIRP and the owner of the intellectual property Houda Amor et al. All Copyright (C) 2014 are guarded by law and by SCIRP as a guardian.

\section{ABSTRACT}

Background: The aim of this study was to establish normal reference values for several growth factors in semen and provide a basis for understanding their physiological significance in fertile and infertile subjects. Methods: 110 infertile men semen was evaluated according to WHO standards and by enzyme immunoassay (ELISA kit protocol) to determine the rate of growth factors (TGF $\beta 1$, IGFI, EGF). We have also listed neutrophils by staining with peroxidase to examine the association of inflammation with the levels of these factors. The determination of the epididymal (alpha-1,4-glucosidase) marker was directed according to the technical recommended by the WHO in 2010. Each patient received a hormonal balance including the determination of plasma FSH, LH and Testosterone. Results: Concentrations of TGF $\beta 1$ were significantly higher in (severe and extreme azoospermic, oligospermic) pathological groups compared to the control group $(P<0.01)$. This is related to the presence of high levels of leukocytes in the sperm, so a possible inflammation in the genital tract. We found no significant difference between the rates of seminal growth factors in patients with normal or elevated plasma FSH. Our results for the IGFI seminal showed no significant difference $(P>0.05)$ between control and pathological groups. The IGFI is partly testicular and/or epididymal as it is lowered in some patients with obstructive azoospermia. Positive correlations were observed between the seminal IGFI, mobility $(r=0.487)$ and sperm morphology $(r=+0.187)$. Immunological sperm abnormalities and/or idiopathic do not alter the rate of EGF seminal. There is no significant correlation between seminal EGF or with sperm parameters or with plasma levels of FSH and LH. Conclusion: The growth factors are primarily peptides, handling and identification in a complex environment as the seminal plasma, but it requires a lot of precautions if we do not want to expose to the risk of bad farms/interpretations of data obtained.

\section{KEYWORDS}

Infertility; Semen; EGF; IGF-I; TGF- $\beta 1$; FSH; LH

\section{INTRODUCTION}

The relation between the growth factors and the human reproduction represents an increasing perimeter of investigations because of their participation in various aspects of the regulation of the physiology of the male fertility including the functions of the endocrine and exocrine testicle. Human sperm contains many growth factors including TGF $\beta 1$ ([1,2]), the EGF [3], the IGF-I and II [4] and many other cytokines and interleukins [5]. However, the seminal concentrations of these factors could not only provide information on their secretions but also reflect the various interactions with the spermatozoa. In vitro, some growth factors which affect the mobility of the human spermatozoa are supraphysio- 
logical concentrations [6] which facilitate the acrosomial reaction and increase the capacity of the spermatozoa to fertilize ovocytes. However, some of these effects are still subject to discussions $[7,8]$. Moreover, it was suggested that an increase in expression of the growth factors could influence the cellular absorption and consequently the regulation of their activity [9]. Recent work showed fluctuations in the concentrations of the growth factors and/or the seminal cytokines, in particular the interleukins (It-1b, It-2, It-6) and/or their soluble receivers (Sr It-2, Sr It-6) in pathological situation, while insisting on their role in the urogenital infections [10-13] like their effect on the numeration and the mobility of the spermatozoa $[14,15]$. Although male infertility is frequently the consequence of the urogenital infection, it can also result from the various causes, which are often multifactorials and/or unexplained. Consequently the seminal concentrations of the growth factors and/or the cytokines can provide extra information in the cases of male infertility.

Our study was devoted to the evaluation of the clinical relevance of the seminal concentrations of the growth factors in the broad sense of the term for the etiologic diagnosis of male infertility. Thus, we analyzed the concentrations of growth factors (IGF-I, TGF- $\beta 1$, EGF) in the seminal plasma of the patients presenting a azoospermia, an extreme oligozoospermia and a severe oligozoospermia which we were confronted with other particular spermatic, biochemical parameters like the hormonal evaluation including the FSH, the $\mathrm{LH}$ and the plasmatic testosterone.

\section{MATERIALS AND METHODS}

\subsection{Population}

Human semen was collected and evaluated from 14 fertile patients and 96 infertile patients who were addressed to the laboratory of Cytogenetic, Molecular Biology and Reproductive Biology. In the infertile population, 43 men presented with azoospermia, 23 men presented with extreme oligozoospermia and 30 men presented with severe oligozoospermia (Table 1). These patients were the subject of a complete clinical investigation: antecedents, clinical examination and in certain cases a scrotal echography. This project was approved by the bioethics committee of the hospital and informed consent was obtained from the participants.

A written consent of each subject was taken after explaining the aims and objectives of the study and its benefits on individual and society. Also, the study was approved by the Local Ethic Committee of the Farhat Hached University Hospital, Sousse (Tunisia).

\subsection{Methods}

Semen samples were collected in specific sterile con-
Table 1. General characteristics of the study population.

\begin{tabular}{cccc}
\hline Parameters & Characteristics & $\begin{array}{c}\text { Number } \\
\text { (n) }\end{array}$ & $\begin{array}{c}\text { Percentage } \\
\text { (\%) }\end{array}$ \\
\hline \multirow{2}{*}{ Age (years) } & $\leq 30$ & 33 & 30 \\
Duration of & $>30$ & 77 & 70 \\
infertility (years) & $\leq 10$ & 88 & 80 \\
\multirow{2}{*}{ Type of infertility } & $>10$ & 22 & 20 \\
& Primary & 79 & 72 \\
Area & secondary & 31 & 28 \\
& Rural & 31 & 28 \\
& urban & 79 & 72 \\
Sperm criteria & Normospermics & 14 & 15.4 \\
& Azoospermics & 43 & 47.3 \\
& Extremoligospermics & 23 & 25.3 \\
& Severe oligospermics & 28 & 30.8 \\
\hline
\end{tabular}

tainers after at least 3 days of sexual abstinence and were allowed to liquefy. After liquefaction of the semen, sperm parameters were evaluated according to published recommendations of the World Health Organization (2010). The proportioning of the epididymal marker (alpha-1,4-glucosidase) was carried out according to the techniques recommended by WHO 2010. The proportioning of seminal growth factors (TGF- $\beta 1$, IGF-I, EGF) was carried out by ELISA. The ELISA kits were obtained from RayBiotech Laboratories (Norcross GA). Each patient underwent hormonal evaluation including a plasmatic proportioning of FSH, LH and Testosterone. The thresholds of normality values were adjusted according to standards established by the International Nomenclature. The bilateral testicular biopsy was practiced when the rate of FSH was regarded as normal for certain azoospermia subjects.

\section{Statistical Analysis}

The mean levels of seminal plasma growth factors parameters were expressed as means \pm SD. Differences among different studied groups were assessed by SPSS 16.0 followed by protected least significant difference student's test (T-test for independent samples). Pearson correlation analysis was conducted to investigate the relationship between variables. Values were considered statistically significant when $\mathrm{P}<0.05$ ( $\mathrm{P}<0.05=$ significant; $\mathrm{P}<0.001$ = highly significant).

\section{RESULTS}

\subsection{TGF $\beta 1$ in Seminal Plasma}

In the control group, the plasmatic concentrations of TGF $\beta 1$ vary between 3 and $183 \mathrm{ng} / \mathrm{ml}$ (Table 2). In the pathological groups (azoospermia, extreme oligozoospermia, severe oligozoospermia), the plasmatic concentrations of the TGF $\beta 1$, are higher compared to the control group but the difference is not statistically significant (NS; P > 0.05). In the group of no obstructive azoosper- 
Table 2. Median values of the spermatic parameters and the seminal growth factors for the pathological and control groups.

\begin{tabular}{|c|c|c|c|c|}
\hline & \multicolumn{4}{|c|}{ Groups } \\
\hline & $\mathbf{I}$ & II & III & IV \\
\hline IGF-I (ng/ml) & $13.3 \pm 1.1$ & $13.1 \pm 4.7$ & $20.2 \pm 3.2$ & $14.3 \pm 4.1$ \\
\hline TGF $\beta_{1}(\mathbf{n g} / \mathbf{m l})$ & $54.0 \pm 4.9$ & $104.3 \pm 105.8$ & $104.9 \pm 48.3$ & $74.2 \pm 66.2$ \\
\hline EGF (ng/ml) & $114.4 \pm 146.1$ & $102.6 \pm 77.9$ & $112.1 \pm 112.3$ & $134.4 \pm 222.3$ \\
\hline $\mathrm{V}(\mathrm{ml})$ & $3.41 \pm 1.1$ & $3.00 \pm 1.4$ & $2.8 \pm 1.2$ & $3.0 \pm 1.1$ \\
\hline Numeration $\left(\times 10^{6} / \mathrm{ml}\right)$ & $69.3 \pm 49.4$ & 0 & $0.41 \pm 0.31$ & $2.7 \pm 0.9$ \\
\hline Anormal morphology (\%) & $65.7 \pm 5.6$ & - & $94.5 \pm 5.8$ & $90.8 \pm 7.3$ \\
\hline Mobility (a + b) (\%) & $29.5 \pm 5.2$ & - & $0.7 \pm 0.4$ & $4.6 \pm 8.4$ \\
\hline Leucospermy $\left(\times 10^{6} / \mathrm{ml}\right)$ & 0 & $0.3 \pm 0.8$ & $1.1 \pm 3.3$ & $0.7 \pm 1.6$ \\
\hline
\end{tabular}

mia, the median value of the seminal TGF $\beta 1$ was 91.42 $\mathrm{ng} / \mathrm{ml}$ against $54.00 \mathrm{ng} / \mathrm{ml}$ for the control group, still higher than the other pathological groups. However, the test F of comparison of the averages (One-Way ANOVA) did not show a significant difference. In this group no significant difference was found between the seminal concentrations of the TGF $\beta 1$, in subjects with normal levels of plasmatic FSH, LH and Testosterone (TGF $\beta 1=$ $48.96 \pm 50.37 \mathrm{ng} / \mathrm{ml}$ ) and the other patients ,of the same group, with a high plasmatic rate of FSH, LH and Testosterone (TGF $\beta 1=91.42 \pm 6.77 \mathrm{ng} / \mathrm{ml}$ ) (Table 3). There was no significant correlation between the rate of the TGF $\beta 1$ and the spermatic parameters (numeration, mobility, morphology). However, the highest rates were observed in the sperm samples obtained from individuals carrying an epididymite. A significant correlation was observed between the TGF $\beta 1$ and the rate of plasmatic FSH ( $\mathrm{r}=0.357 ; \mathrm{P}<0.05)$ and between the TGF $\beta 1$ and the rate of plasmatic LH $(r=0.294$; $\mathrm{P}>0.05)$. On the other hand the correlation was negative between the TGF $\beta 1$ and the rate of plasmatic Testosterone $(\mathrm{r}=-0.003, \mathrm{P}>$ $0.05)$.

\subsection{EGF in Seminal Plasma}

The EGF was determined by ELISA in the control group (the median value of the seminal EGF was $114.4 \pm$ $146.01 \mathrm{ng} / \mathrm{ml}$ ) and in the pathological groups (azoospermia, extreme oligozoosperma, severe oligozoosperma). The statistical analysis did not show a significant difference between the control group and the pathological groups relating to this factor (Control: EGF $=144.4$ $\mathrm{ng} / \mathrm{ml}$; azoospermia: EGF = $102.68 \mathrm{ng} / \mathrm{ml}$; extreme oligozoospermia: $\mathrm{EGF}=112.09 \mathrm{ng} / \mathrm{ml}$; severe oligozoospermia: $\mathrm{EGF}=134.44 \mathrm{ng} / \mathrm{ml}$ ). In addition, all the correlations observed between the EGF and the parameters of the analysis sperm were negative whatever the pathological studied group (Table 3 ). In addition, we did not ob- serve a significant correlations between the seminal biochemical marker (Alpha-1,4-glucosidase) and the seminal factor EGF.

\subsection{IGF-I in Seminal Plasma}

The median value of the rate of the IGF-I in seminal plasma was estimated at $13.33 \pm 1.15 \mathrm{ng} / \mathrm{ml}$. This value was not significantly different from the actual value in the pathological groups (azoospermia: IGF-I $=13.15 \pm$ $4.70 \mathrm{ng} / \mathrm{ml}$; extreme oligozoospermia: IGF-I = $20.23 \pm$ $3.2 \mathrm{ng} / \mathrm{ml}$; severe oligozoospermia: IGF-I = $14.31 \pm 4.01$ $\mathrm{ng} / \mathrm{ml})$. The analysis of the correlations (test of Spearman) showed a positive correlation between the concentration of the IGF-I, in seminal plasma, the morphology of the spermatozoa $(r=0.187)$ and the mobility of the spermatozoa ( $\mathrm{r}=+0.487)$, but a negative correlation with numeration $(\mathrm{r}=-0.027 ; \mathrm{P}>0.05)$ (Table 3$)$. In addition we did not note a significant correlation between the rate of the IGF-I and the rate of plasmatic FSH $(r=0.080$; $\mathrm{P}>$ $0.05)$ or the plasmatic LH $(r=-0.059, \mathrm{P}>0.05)$.

\subsection{Variation of the Rates of the Seminal Growth Factors in the Azoospermia Subjects}

The selection of the obstructive azoospermia and the no obstructive azoospermia was based on the data of the plasmatic FSH and seminal alpha-1,4-glucosidase. Thus two groups could be defined. The first contains patients with a normal FSH (1.5 - $10 \mathrm{mUI} / \mathrm{ml})$ and a low alpha-1, 4-glucosidase (<20 mUI) (obstructive azoospermia: $\mathrm{n}=$ 11). The second contains patients with high FSH $(>10$ $\mathrm{mUI} / \mathrm{ml}$ ) and normal alpha-1,4-glucosidase ( $\geq 20 \mathrm{mUI})$ (no obstructive azoospermia: $n=32$ ). The average rates of the growth factors in the two groups are provided in Table 4. We compared the distribution between obstruction of the genital ways and defect of the spermatogenesis with that obtained by considering respectively the value 
Table 3. distribution of pathological subjects on the basis of plasma hormone (FSH and LH).

\begin{tabular}{|c|c|c|c|c|}
\hline & & \multicolumn{3}{|c|}{ Growth factors } \\
\hline Groups & Plasmatic rates of the gonadotrophins & TGF- $\beta_{1}(\mathrm{ng} / \mathrm{ml})$ & EGF (ng/ml) & IGF-I (ng/ml) \\
\hline A & $\begin{array}{c}\text { FSH }>10 \mathrm{mUI} / \mathrm{ml} \\
\mathrm{LH}>10 \mathrm{mUI} / \mathrm{ml}\end{array}$ & $91.4 \pm 6.7(8-183)$ & $107.1 \pm 104.2(24-400)$ & $11.25 \pm 4.85(4-14)$ \\
\hline B & $\begin{array}{c}\mathrm{FSH} \leq 10 \mathrm{mUI} / \mathrm{ml} \\
\mathrm{LH} \leq 10 \mathrm{mUI} / \mathrm{ml}\end{array}$ & $48.9 \pm 50.3(3-153)$ & $176.7 \pm 240.3(34-800)$ & $14.4 \pm 3.6(9-22)$ \\
\hline $\mathbf{C}$ & $\begin{array}{c}\mathrm{FSH}>10 \mathrm{mUI} / \mathrm{ml} \\
\mathrm{LH} \leq 10 \mathrm{mUI} / \mathrm{ml}\end{array}$ & $49.3 \pm 5.3(3-120)$ & $73.3 \pm 26.3(38-128)$ & $15.0 \pm 1.7(14-18)$ \\
\hline $\mathbf{D}$ & $\begin{array}{c}\mathrm{FSH} \leq 10 \mathrm{mUI} / \mathrm{ml} \\
\mathrm{LH}>10 \mathrm{mUI} / \mathrm{ml}\end{array}$ & $24.0(24-24)$ & $102.0(102-102)$ & $11.0 \pm 4.2(8-14)$ \\
\hline
\end{tabular}

Based on levels of pituitary hormones, we could leave the subjects into four groups. We did not consider sperm parameters for this distribution. In each hormone group (A, B, C, D), one can find subjets of four initial pathological groups (I, II, III, IV).

Table 4. Average rate of the seminal growth factors for the azoospermia subjects, (a) FSH value only, (b) Alpha-1,4-glucosidase marker only, (c) Combined Biologic Parameters.

(a)

\begin{tabular}{cccc}
\hline & & Growth factor & \\
\hline FSH plasmatique (mUI/ml) & TGF $\boldsymbol{\beta}_{\mathbf{1}}(\mathbf{n g} / \mathbf{m l})$ & EGF (ng/ml) & IGF-I (ng/ml) \\
\hline Normal $(\mathbf{1 . 5} \mathbf{- 1 0} \mathbf{~} \mathbf{~ U I / m l )}$ & $50.9 \pm 52.6$ & $179.0 \pm 228.8$ & $14.0 \pm 3.5$ \\
Elevated $(>\mathbf{1 0} \mathbf{~} \mathbf{m U} / \mathbf{m l})$ & $77.1 \pm 63.6$ & $89.8 \pm 78.0$ & $13.8 \pm 3.3$ \\
\hline
\end{tabular}

(b)

\begin{tabular}{cccc}
\hline & \multicolumn{3}{c}{ Growth factor } \\
\hline Alpha-1,4-glucosidase (mUI) & TGF $\boldsymbol{\beta}_{\mathbf{1}}$ (ng/ml) & EGF $\mathbf{( n g} / \mathbf{m l})$ & IGF-I (ng/ml) \\
\hline Normal ( $\geq \mathbf{2 0}$ mUI) & $62.1 \pm 58.6$ & $107.3 \pm 85.4$ & $14.7 \pm 3.0$ \\
low(<20 $\mathbf{~ m U I )}$ & $64.8 \pm 62.8$ & $171.0 \pm 156.4$ & $14.1 \pm 0.9$ \\
\hline
\end{tabular}

(c)

\begin{tabular}{|c|c|c|c|}
\hline \multirow[b]{2}{*}{ FSH (mUI/ml) + Alpha-1,4-glucosidase (mUI) } & \multicolumn{3}{|c|}{ Growth factor } \\
\hline & TGF $\beta_{1}(\mathbf{n g} / \mathbf{m l})$ & EGF (ng/ml) & IGF-I (ng/ml) \\
\hline Alpha-glucosidase low (<20 mUI/) + FSH normal (1.5 - 10 mUI/ml) & $20.0 \pm 15.3$ & $108.0 \pm 79.8$ & $14.2 \pm 1.1$ \\
\hline Alpha-glucosidase normal ( $\geq 20 \mathrm{mUI})+$ FSH elevated $(>10 \mathrm{mUI} / \mathrm{ml})$ & $50.9 \pm 52.6$ & $179.0 \pm 228.8$ & $14.0 \pm 3.5$ \\
\hline Alpha-glucosidase normal $(\geq 20 \mathrm{mUI})+$ FSH normal $(1.5$ - $10 \mathrm{mUI} / \mathrm{ml})$ & $56.1 \pm 59.6$ & $130.0 \pm 120.8$ & $14.6 \pm 3.9$ \\
\hline
\end{tabular}

of the plasmatic FSH and seminal alpha-1,4-glucosidase. 18 patients had an average rate of TGF $\beta 1$ of $50.97 \pm$ $52.61 \mathrm{ng} / \mathrm{ml}, 21$ patients had a median rate of the EGF equal to $179.05 \pm 228.42 \mathrm{ng} / \mathrm{ml}$ and 17 patients had a median rate of the IGF-I equal to $14.0 \pm 3.53 \mathrm{ng} / \mathrm{ml}$ (Table 4(a)). On the other hand, 14 subjects presented a raised $\mathrm{FSH}$,in spite of a normal biopsy, had an average rate of TGF $\beta 1$ equal to $77.14 \pm 63.61 \mathrm{ng} / \mathrm{ml}$, whereas 21 subjects had a rate of EGF equal to $89.80 \pm 78.01 \mathrm{ng} / \mathrm{ml}$ and only 13 subjects had a rate of IGF-I equal to $13.84 \pm$ $3.33 \mathrm{ng} / \mathrm{ml}$. The proportioning of alpha-1,4-glucosidase (Table 4(b)) revealed the existence of an obstruction in 18 cases out of 49 (36.7\%). In 13 subjects the average rate of TGF $\beta 1$ was equal to $62.19 \pm 5.86 \mathrm{ng} / \mathrm{ml}, 15 \mathrm{sub}-$ jects had a rate of EGF equal to $107.33 \pm 85.48 \mathrm{ng} / \mathrm{ml}$ and for only 11 cases the rate of the IGF-I was equal to $14.72 \pm 3.00 \mathrm{ng} / \mathrm{ml}$. For certain cases, presenting a low rate of alpha glucosidase, a stop of the spermatogenesis had been checked by the testicular biopsy. The majority of the men presenting a no obstructive azoospermia ,not having undergone surgical exploration of the scrotum, an associated obstructive pathology could not be excluded. The combination of two parameters (alpha-1,4-glucosidase and FSH; Table 4(c)) led to new values of the growth factors which really correspond to true cases of obstructive or no obstructive azoospermia. The observation of a normal FSH in combination with a normal epididymal marker also proved to be relatively common: 7 
men out of 43. For those cases where the cause of azoospermia remained undetermined, histological examination of testicular biopsies became necessary to clarify the etiology: spermatogenesis was normal for 5 men and was blocked in the course of meiosis (zygoten and pachyten stage) for the two others. For one of the patients who had normal spermatogenesis, we examined histologically the rete testis, which proved totally fibrotic leucospermia influence on the values of seminal growth factors in various pathological groups (Table 5).

\subsection{Cases of Azoospermia}

We analyzed 43 azoospermic semen including 21 with complete absence of the leucocytes in sperm (group 1) and 22 with leucospermia (group 2). The average rates of the growth factors in group 1 were $90.88 \pm 68.80 \mathrm{ng} / \mathrm{ml}$ for the TGF $\beta 1 ; 82.00 \pm 24.84 \mathrm{ng} / \mathrm{ml}$ for the EGF and of $14.57 \pm 1.51 \mathrm{ng} / \mathrm{ml}$ for the IGF-I. For group 2, the rates were $36.50 \pm 17.02 \mathrm{ng} / \mathrm{ml}$ for the TGF $\beta 1 ; 129.75 \pm$ $111.42 \mathrm{ng} / \mathrm{ml}$ for the EGF and $12.00 \pm 5.29 \mathrm{ng} / \mathrm{ml}$ for the IGF-I. Then, for the studied growth factors, there was no significant difference between those two groups $(\mathrm{P}>$ 0.05).

\subsection{Cases of Extreme Oligozoospermia}

The analysis is carried out in 23 sperm with sperm concentration between 10,000 and 1 million sperm $/ \mathrm{ml}$ including 17 without leucospermia and 6 with leucospermia. For the subjects without leucospermia (17/23), the average rates of the growth factors were $58.25 \pm$ $61.79 \mathrm{ng} / \mathrm{ml}$ for the TGF $\beta 1 ; 117.33 \pm 108.88 \mathrm{ng} / \mathrm{ml}$ for the EGF and $16.71 \pm 2.21 \mathrm{ng} / \mathrm{ml}$ for the IGF-I. For the subjects with leucospermia (6/24), the average rates of the growth factors were $85.00 \pm 56.47 \mathrm{ng} / \mathrm{ml}$ for the TGF $\beta 1 ; 146.00 \pm 171.76 \mathrm{ng} / \mathrm{ml}$ for the EGF and $11.00 \pm 4.24$ $\mathrm{ng} / \mathrm{ml}$ for the IGF-I. For the studied factors, the difference remains no significant between the two categories of subjects.

\subsection{Cases of Severe Oligozoospermia}

We analyzed 30 sperm with a sperm concentration between 1 and 5 million/ml, including 12 without leucospermia and 18 with a leucospermia which varies between $0.1 \times 10^{6}$ and $7.4 \times 10^{6} / \mathrm{ml}$. The average rates of the growth factors are provided in Table 5. The difference was not significant for the 3 studied factors. The calculation of the coefficient of correlation between the concentration of sperm on leucocytes and the seminal growth factors shows that there is no significant correlation between these parameters (TGF $\beta 1$ : $\mathrm{r}=-0.095$, NS; EGF: $r=-0.08$, NS; IGF-I: $r=-0.250$, NS) whatever the sperm count.

\section{DISCUSSION}

Our objectives were to evaluate the concentration of the seminal growth factors by ELISA, to determine if there are differences in the seminal concentrations of these growth factors between control subjects and infertile subjects and to show the interest of the determination of these factors in determining the etiology of infertility. We found high concentrations of TGF $\beta 1$ in the seminal plasma of the infertile patients compared to the concentrations in the control patients. In our study the normal values of activated TGF $\beta 1$ were very changing in seminal plasma for controls or pathological groups like all the parameters of the seminal plasma from 3 to $183 \mathrm{ng} / \mathrm{ml}$. Normal values of latent TGF $\beta 1$ obtained in our study were $54.00 \pm 4.92 \mathrm{ng} / \mathrm{ml}$ (for controls)are similar to those reported by other authors [16] $(71.0 \pm 32.1 \mathrm{ng} / \mathrm{ml}$ in 3 samples of seminal plasma of normal subjects), but lower than those obtained by another team [17] (238 ng/ml in 4 groups of samples of seminal plasma coming from vasectomized subjects). The absence of a significant difference between the concentrations of TGF $\beta 1$, in presence or absence of an epididymal obstruction where testicular secretions can not contribute in the formation of seminal plasma and the absence of correlation between

Table 5. Average rates of the seminal growth factors according to the presence or absence of the leucocytes in sperm for the pathological groups.

Growth factors

\begin{tabular}{|c|c|c|c|c|}
\hline Groups & & TGF $\beta_{1}(\mathrm{ng} / \mathrm{ml})$ & EGF (ng/ml) & IGF-I (ng/ml) \\
\hline \multirow{2}{*}{ II: Azoospermia $(n=42)$} & Without leucospermia & $90.8 \pm 68.8$ & $82.0 \pm 24.8$ & $14.5 \pm 1.5$ \\
\hline & With leucospermia & $36.5 \pm 17.0$ & $129.7 \pm 114.4$ & $12.0 \pm 5.2$ \\
\hline \multirow{2}{*}{$\begin{array}{c}\text { III: Extreme } \\
\text { Oligospermia }(n=28)\end{array}$} & Without leucospermia & $58.2 \pm 61.7$ & $117.3 \pm 108.8$ & $16.7 \pm 2.2$ \\
\hline & With leucospermia & $85.0 \pm 56.4$ & $146.0 \pm 171.8$ & $11.0 \pm 4.2$ \\
\hline \multirow{2}{*}{$\begin{array}{c}\text { IV: Severe } \\
\text { Oligospermia }(n=24)\end{array}$} & Without leucospermia & $39.3 \pm 53.7$ & $61.2 \pm 19.6$ & $15.6 \pm 3.5$ \\
\hline & With leucospermia & $72.5 \pm 71.0$ & $234.2 \pm 34.9$ & $12.8 \pm 3.0$ \\
\hline
\end{tabular}


TGF $\beta 1$ and alpha-1,4-glucosidase (epididymal marker) suggest that the testicle and the epididymis contribute partly to the secretion of TGF $\beta 1$ found in seminal plasma. It would be interesting to determine the exact origin of extra testicular seminal TGF $\beta 1$.

In addition, there was no significant difference in the concentrations of seminal TGF $\beta 1$ between the subjects with elevated FSH and LH, and the subjects with a normal hormonal assessment, suggesting once again that TGF $\beta 1$ is probably not under hormonal testicular control.

A role of this growth factor TGF $\beta 1$ in the regulation of the growth and the functions of the somatic testicular cells was shown in vitro $[18,19]$, however, we have observed, in our study, a significant differences between the concentrations of TGF $\beta 1$ in controlos and pathological groups (azoospermia, extreme oligozoospermia, severe oligozoospermia) probably because other areas of the genital tract secrete this ligand. Moreover, the ligand measured by ELISA is part of all the TGF $\beta$ system, which includes, in addition to the ligand, the proteins of transport and the receiver's membrane. Consequently, a possible difference between the normal and pathological subjects could be found on the level of these parameters. While being based on this observation, it would be interesting to analyze these parameters in the seminal plasma of the sterile men. Finally, although we found high concentrations of TGF $\beta 1$ in the pathological groups (azoospermia, extreme oligozoospermia, severe oligozoospermia), we do not know at present whether these observations are relevant to their infertility. A larger number of patients would be necessary to draw a firm conclusion on this question. Our results show that the seminal concentrations of TGF $\beta 1$ are higher in sperms with leucospermia compared to the concentrations of the same ligand in sperms without leucospermia and this is whatever the pathological group under consideration except of the azoospermic ones. This can indicate a local action of the ligand after an infection or an inflammation [20]. An immunosuppressive activity was shown in seminal plas$\mathrm{ma}[21]$ and it was assigned to the prostaglandins [22] and other local factors [23]. Then the TGF $\beta 1$ can contribute in this activity [24].

As for to the insulin-like growth Factor I (IGF-I), the results showed that this peptide is present in human seminal plasma in controls and infertile patients. In humans, the origin of the seminal IGF-I was determined by examining semen samples before and after vasectomy [25]. These authors concluded that the high concentrations of the seminal IGFI after vasectomy would come from the prostate while the low concentrations of the same ligand would be from epididymal and/or testicular origin. After vasectomy, the concentration of seminal IGF-I is reduced by one third compared to the concentration before the surgery, allowing authors to conclude that IGF-I is mainly testicular and/or epididymal. To confirm or cancel this assumption we were interested in the group of the azoospermic subjects (43 cases). Indeed, the differential diagnosis of these azoospermic patients is primarily based on the rate of plasmatic FSH, the activity of alpha-1,4-glucosidase and in certain cases the results of the testicular biopsy. It is now known that the value of the plasmatic FSH informs about the state of the spermatogenesis. Indeed, when the FSH is high ( $>10 \mathrm{mUI} / \mathrm{ml})$, the mechanisms of feedback control by the inhibin, Sertoli cells origin, are failing and the FSH increases. Conversely, a normal value of FSH reflects a satisfactory secretion of inhibin, indirect sign of the correct course of spermatogenesis. To the extent where we are in the presence of azoospermia, we therefore concluded an obstruction of sperm ducts. However, the plasmatic FSH does not constitute a parameter having an absolute reliability: on the one hand, the two types of obstructive and no obstructive pathology are always likely to coexist. For this reason we considered the combination of the two parameters: the plasmatic FSH and seminal alpha-1,4-glucosidase to define a correct diagnosis of the azoospermia. Indeed, in the obstructive azoospermia, it exists a whole range of values of the variable IGF-I between 13 and 16 $\mathrm{ng} / \mathrm{ml}$. Thus it is conceived easily that the lowest values corresponding to low obstructions (tail of the epididymis or even vas deferens, which corresponds to the situation of the vasectomized subjects) in agreement with work of other autors [26]. Over the obstruction is located high over the values of IGF-I approximate the normal (18 $\mathrm{ng} / \mathrm{ml}$ [26]); $20 \mathrm{ng} / \mathrm{ml}$ [27]. On the other hand, if the obstruction is located upstream from the site where the secretion of IGF-I appears, the value of this ligand will be normal corresponding to the situation where the FSH and alpha-glucosidase are normal (Table 4(c)). Then, we can say that the presence of the IGF-I in seminal plasma after vasectomy or a close situation to low obstruction of the spermatic ways suggests that the additional glands (prostate, blisters seminal, bulb-urethral glands) also produce the IGF-I. Thus, it would be interesting to determine the exact origin of the seminal IGF-I.

The relations between the seminal IGF-I and the parameters of the sperm analysis (Numeration, mobility, morphology) were studied. The mobility and the percentage of normal forms of the spermatozoa were higher in the sperm samples with high concentration of seminal IGF-I. On one hand, a positive correlation between the morphology and the seminal IGF-I was noted $(r=+0.187$, $\mathrm{P}>0.05$ ) and the seminal IGF-I and the mobility on the other hand $(r=+0.487, \mathrm{P}<0.05)$.

Although the effect of the seminal IGF-I on the function of the human spermatozoa and the domestic species 
is not completely elucidated, several work confirmed that the vesicular proteins are implied in the function of the spermatozoa. The study of the phenomena of regulation of the capacitation and the acrosomial reaction make it possible to define the physiological role of seminal IGFs. By using the data of all the individuals (confused groups), no correlation was found between the seminal IGF-I and the rate of plasmatic FSH or LH. This result testifies that the cells of Sertoli (target of the FSH) are not concerned with the secretion of the IGF-I. Moreover, high rates of plasmatic FSH were always associated with low concentrations of seminal IGF-I.

The study of the seminal factor EGF showed that the rate of this factor is always higher than $100 \mathrm{ng} / \mathrm{ml}$ whatever the considered group $(114.4 \mathrm{ng} / \mathrm{ml}$ for the control group; $102.68 \mathrm{ng} / \mathrm{ml}$ for the azoospermic men; 112.09 $\mathrm{ng} / \mathrm{ml}$ for the extreme oligospermic men and 134.44 $\mathrm{ng} / \mathrm{ml}$ for the severe oligospermic men). Statistically, there was no significant difference between the rates of the seminal EGF in the control and pathological groups (infertile patients) indicating that the idiopathic or immunological factors do not have an effect on the concentration of the seminal EGF. There was no correlation between the rate of the seminal EGF, spermatic numeration, and the mobility of the spermatozoa which stating probably that these parameters are not influenced by the physiological concentration of the EGF.

\section{CONCLUSION}

Finally, seminal plasma, which is the result of gonadal and extra-gonadal secretions could identify markers of different types of molecules and trace secretary and excretory azoospermia. The growth factor being primarily peptides, and their manipulation identification in a complex environment such as seminal plasma, however, requires a lot of precautions if you do not want to expose themselves to the risk of poor farm/interpretations of the data obtained. The information provided by biochemistry seminal is crucial for the diagnosis of sepsis and/or inflammatory glands, they also allow differentiating the different types of azoospermia and sometimes even specify the location of occlusion. New approaches such as evaluation of growth factors in human sperm are present in the study and still require further explorations to be validated and explain more precisely the sperm and seminal plasma interactions, impaired membrane permeability or certain enzyme deficiencies.

\section{ACKNOWLEDGEMENTS}

This work was supported by the budget of the laboratory of cytogenetic, molecular Biology and Human reproductive Biology under the code.

\section{CONFLICT OF INTERESTS}

The author has declared that no conflict of interest exists.

\section{REFERENCES}

[1] Nocera, M.A. and Chu, T.M. (1993) Transforming growth factor-b as an immunosuppressive protein in human seminal plasma. American Journal of Reproductive Immunology, 30, 1-8.

http://dx.doi.org/10.1111/j.1600-0897.1993.tb00594.x

[2] Yie, S.M., Lobb, D.K., Clark, D.A. and Younglai, E.V. (1994) Identification of a transforming growth factor alpha-like molecule in human seminal plasma. Fertility and Sterility, 61, 129-135.

[3] Hirata, Y., Uchihashi, M., Hazama, M. and Fujita, T. (1987) Epidermal growth factor in human seminal plasma. Hormone and Metabolic Research, 19, 35-37. http://dx.doi.org/10.1055/s-2007-1011730

[4] Macpheron, M.L., Simmen, R.C.M., Simmen, F.A., Hernandez, J., et al. (2002) Insulin-like growth factori and insulin-like growth factor binding protein-2 and -5 in equine seminal plasma: Association with sperm characteristics and fertility. Biology of Reproduction, 67, 648-654. http://dx.doi.org/10.1095/biolreprod67.2.648

[5] Liabakk, N.-B., Lien, E., Sundan, A., et al. (1993) High concentrations of the soluble p55 tumour necrosis factor receptor in human seminal plasma. Human Reproduction, 8, 1837-1842.

[6] Spalekova, E., Makarevich, A.V. and Lukac N. (2011) Ram sperm motility parameters under the influence of epidermal Growth factor. Veterinary Medicine International, 2011, Article ID: 642931.

http://dx.doi.org/10.4061/2011/642931

[7] Haney, A.F., Hughes, S.F. and Weinberg, J.B. (1992) The lack of effect of tumor necrosis factor-alpha, interleukin1-alpha, and interferon-gamma on human sperm motility in vitro. Journal of Andrology, 13, 249-253.

[8] Wincek, T.J., Meyer, T.K., Meyer, M.R. and Kuehl, T.J. (1991) Absence of a direct effect of recombinant tumor necrosis factor-alpha on human sperm function and murine preimplantation development. Fertility and Sterility, 56, 332-339.

[9] Chu, T.M., Nocera, M.A., Flanders, K.C., et al. (1996) Localization of seminal transforming growth factor-b1 on human spermatozoa: An immunocytochemical study. Fertility and Sterility, 66, 327-330.

[10] Comhaire, F., Bosmans, E., Ombelet, W., et al. (1994) Cytokines in semen of normal men and of patients with andrological diseases. American Journal of Reproductive Immunology, 31, 99-103.

http://dx.doi.org/10.1111/j.1600-0897.1994.tb00853.x

[11] Gruschwitz, M.S., Brezinschek, R. and Brezinschek, H.P. (1996) Cytokine levels in the seminal plasma of infertile males. Journal of Andrology, 14, 158-163.

[12] Miska, W. and Mahmoud, M. (1993) Determination of soluble interleukin-2 receptor in human seminal plasma. Archives of Andrology, 30, 23-28. 
http://dx.doi.org/10.3109/01485019308988364

[13] Rajasekaran, M., Hellstrom, W.J.G., Naz, R.K. and Sikka, S.C. (1995) Oxidative stress and interleukins in seminal plasma during leukocytospermia. Fertility and Sterility, 64, 166-171.

[14] Naz, R.K. and Kaplan, P. (1994) Increased levels of interleukin-6 in seminal plasma of infertile men. Journal of Andrology, 15, 220-227.

[15] Shimonovitz, S., Barak, V., Zacut, D., et al. (1994) High concentration of soluble interleukin-2 receptors in ejaculate with low sperm motility. Human Reproduction, 4, 653-655.

[16] Shrivastava, M.D., Lippes, J. and Shrivastava, B.I. (1996) Cytokines of the human reproductive tract. American Journal of Reproductive Immunology, 36, 157-166. http://dx.doi.org/10.1111/j.1600-0897.1996.tb00157.x

[17] Nocera, M.A. and Chu, T.M. (1995) Characterization of latent transforming growth factor-b from human seminal plasma. American Journal of Reproductive Immunology, 33, 282-291. http://dx.doi.org/10.1111/j.1600-0897.1995.tb00897.x

[18] Benahmed, M. (1996) Growth factors and cytokines in the testis. In: Comhaire, F.H., Ed., Male Infertility. Chapman \& Hall, London, 55-95.

[19] Gnessi, L., Fabbri, A. and Spera, G. (1997) Gonadal peptides as mediators of development and functional control of the testis: An integrated system with hormones and local environment. Endocrine Reviews, 18, 541-609. http://dx.doi.org/10.1210/er.18.4.541

[20] Noble, N.A., Harper, J.R. and Border, W.A. (1992) In vivo interactions of TGF-b and extracellular matrix. Progress in Growth Factor Research, 4, 369-382.
http://dx.doi.org/10.1016/0955-2235(92)90017-C

[21] James, K. and Hargreave, T.B. (1984) Immunosuppression by seminal plasma and its possible clinical significance. Immunology Today, 5, 357-363. http://dx.doi.org/10.1016/0167-5699(84)90079-3

[22] Quaile, A., Kelly, J., Hargreave, R.W., et al. (1989) Immunosuppression by human seminal prostaglandins. Clinical \& Experimental Immunology, 75, 387-391.

[23] Imade, G.E., Baker, H.W.G., de Kretser, D.M. and Hedger, M.P. (1997) Immunosuppressive activities in the seminal plasma of infertile men: relationship to sperm antibodies and autoimmunity. Human Reproduction, 12, 256-262. http://dx.doi.org/10.1093/humrep/12.2.256

[24] Pollanen, P., von Euler, M., Jahnukainen, K., et al. (1993) Role of transforming growth factor $\mathrm{b}$ in testicular immunosuppression. Journal of Reproductive Immunology, 24, 123-137. http://dx.doi.org/10.1016/0165-0378(93)90015-A

[25] Glander, H.J., Kraatzsch, J., Weisbrich, Ch., et al. (1996) Insulin-like growth factor and a2-macroglobulin in seminal plasma correlate with semen quality. Human Reproduction, 11, 2454-2460. http://dx.doi.org/10.1093/oxfordjournals.humrep.a019136

[26] Ovesen, P., Fleyvbjrg, A. and Orskov, H. (1995) Insulin-like growth factor I (IGFI) and IGF-binding proteins in seminal plasma before and after vasectomy in normal men. Fertility and Sterility, 63, 913-918.

[27] Hamamah, S., Soufir, J.C., Hazout, A. and Benahmed, M. (1999) Facteurs de croissance et cytokines: Nouveaux marqueurs gonadiques dans l'evaluation de l'infertilite masculine. Andrologie, 9, 459-469. http://dx.doi.org/10.1007/BF03034662 